\title{
A Neonate with Bicytopenia: Unusual Underlying Etiology
}

\author{
Ahmed Mohamed Elmelhat ${ }^{\mathrm{a}}$ Manal Mustafa Khadora ${ }^{\mathrm{b}}$ \\ a Department of Pediatrics, NICU, Latifa Women and Children Hospital (LWCH), Dubai, United Arab Emirates; \\ ${ }^{b}$ Department of Pediatrics, Endocrinology, Latifa Women and Children Hospital (LWCH), \\ Dubai, United Arab Emirates
}

\section{Keywords}

Bicytopenia · Hypothyroidism • Leukopenia · Neonate ·

Thrombocytopenia

\begin{abstract}
Although bicytopenia or pancytopenia is an uncommon presentation in the neonatal intensive care units setup, it still carries a wide range of differential diagnoses ranging from simple benign to complex malignant etiologies. We report an unusual etiology of a neonatal bicytopenia and discuss our approach of management.

(C) 2019 The Author(s) Published by S. Karger AG, Basel
\end{abstract}

\section{Introduction}

Thyroid hormones may regulate hematopoiesis in the bone marrow. There is an association of thyroid disorders with abnormalities in hematological parameters. Charcot in 1881 showed that Graves' disease is associated with anemia. Hypothyroidism can cause certain kinds of anemia and proliferation of immature erythroid progenitors. Usually, anemia is macrocytic hypochromic [1].

All hematological parameters return to normal after achieving an euthyroid state [2]. White blood cells, neutrophils, and thrombocytes showed a slight decrease in hypothyroid patients [3]. In hyperthyroid patients, ele- vated, normal, or slightly decreased total leukocyte counts have been found and a relative decrease in neutrophil number and a relative increase in the number of eosinophils and mononuclear cells. Nevertheless, there was hyperplasia of all myeloid cell lines in hyperthyroid states and hypoplasia in hypothyroid patients, as reported by Axelrod and Berman [4].

\section{Case Report}

A late preterm male baby weighing $1,845 \mathrm{~kg}$ (below the $3 \mathrm{rd}$ centile) was born at 36 weeks' gestational age to a 36 -year-old fifth gravida mother with a history of two ectopic pregnancies and one baby having died in the neonatal period because of Potter's syndrome. He is a product of non-consanguineous marriage. The mother was rubella immune with negative serology. She is euthyroid with no history of diabetes mellitus or hypertension. High vaginal swab was positive for Streptococci, beta hemolytic group B, and midstream urine sample showed no growth. His antenatal ultrasound showed symmetrical intrauterine growth retardation, normal amniotic fluid index, and normal Doppler through the umbilical vessels.

The baby was delivered by emergency lower segment cesarean section due to fetal distress through clear liquor. He cried immediately after birth with Apgar scores of 8 and 9 at 1 and $5 \mathrm{~min}$, respectively. He developed respiratory distress shortly after birth, so he was transferred to the NICU for further management.

In the NICU, his physical examination was normal apart from mild tachypnea and grunting; other systemic examination including neurological examination was unremarkable. He was hooked to neoblend for a few hours then weaned to room air. His chest

\section{KARGER}

E-Mail karger@karger.com www.karger.com/dmj
(C) 2019 The Author(s)

Published by S. Karger AG, Basel

Karger

Open access

This article is licensed under the Creative Commons AttributionNonCommercial-NoDerivatives 4.0 International License (CC BY NC-ND) (http://www.karger.com/Services/OpenAccessLicense). Usage and distribution for commercial purposes as well as any distribution of modified material requires written permission.
Dr. Ahmed Elmelhat

Pediatric Department/Neonatal Intensive Care Unit

Latifa Women and Children Hospital (LWCH)

PO Box 4545, Oud Maitha Street, Dubai (United Arab Emirates)

E-Mail Ahmedelmelhat@dha.gov.ae 
Fig. 1. Thyroid scintigraphy.
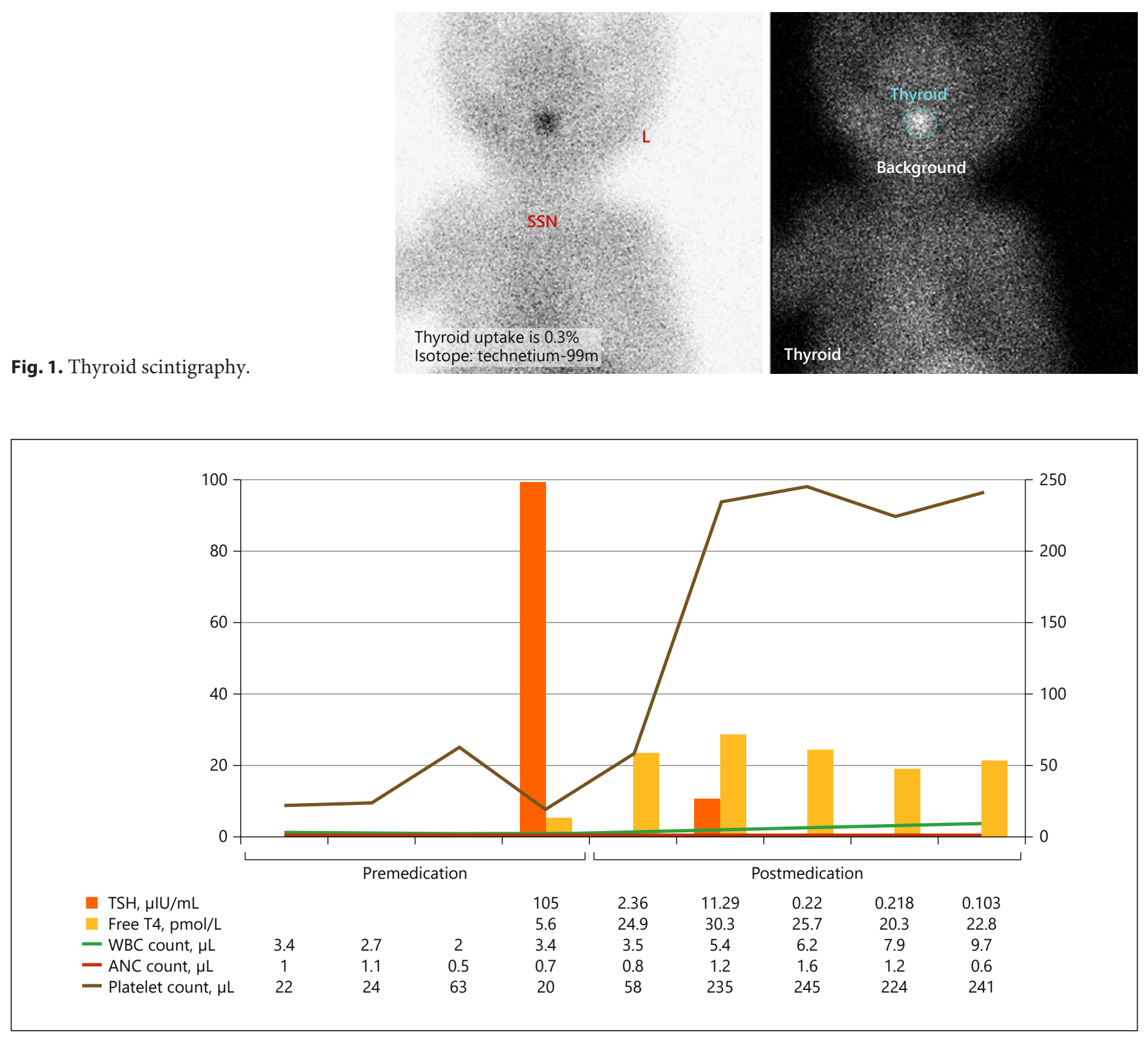

Fig. 2. Blood indices before and after L-thyroxine treatment and relation to thyroid hormone levels.

X-ray showed mild lung haziness with fluid in the lung fissure. Antibiotics received, his initial CRP was negative. His initial full blood count (FBC) showed leukopenia, neutropenia, and severe thrombocytopenia with total white blood cell (WBC) count 3,400/ $\mu \mathrm{L}$ (normal range 4,000-26,000/ $\mathrm{L}$ ), absolute neutrophil count $1,000 / \mu \mathrm{L}$ (normal range $4,000-14,000 / \mu \mathrm{L}$ ), and platelet count $22,000 / \mu \mathrm{L}$ (normal range 100,000-450,000/ $\mu \mathrm{L}$ ).

As a part of the investigations, blood film showed severe thrombocytopenia, leukopenia, a mild increase in polychromatic cells with presence of few nucleated red cells, numerous acanthocytes, no fragmented cells, and an occasional microspherocyte was noted. Reticulocytic count was within normal levels. Screening for con- genital viral infections (TORCH) was negative. Direct agglutination test was negative. Abdominal and cranial ultrasounds both were normal. Both renal and liver function tests were normal. Serial follow-up of the FBC showed persistent leukopenia, neutropenia, and thrombocytopenia. As the initial impression by the hematologist for possible cause was related to prematurity and intrauterine growth restriction, he advised to avoid bone marrow aspirate and not to give recombinant granulocyte-macrophage-colony stimulating factor but only for serial blood indices follow-up.

On day 9 of age, the newborn screening was positive for glucose 6 phosphate dehydrogenase (G6PD) deficiency and congenital hypothyroidism. It showed a severe rise in TSH to $534.3 \mu \mathrm{IU} / \mathrm{mL}$. 
Table 1. Causes of neonatal cytopenia

\begin{tabular}{|c|c|}
\hline Decreased production & Increased destruction/sequestration \\
\hline $\begin{array}{l}\text { Primary } \\
\text { - Malignancy/leukemia/marrow infiltration } \\
\text { - Genetic disorders: chromosomal anomalies (aneuploidies, e.g., } \\
\text { trisomies), mitochondrial disease (Pearson's syndrome) } \\
\text { - Inborn error of metabolism (proprionic and methylmalonic } \\
\text { acidemia) } \\
\text { - Inherited bone marrow failure syndromes (IBMFS) } \\
\text { Manifested in the neonatal period: } \\
\text { - Thrombocytopenia absent radii (TAR) syndrome } \\
\text { - Severe congenital neutropenia (SCN) } \\
\text { - Diamond-Blackfan anemia } \\
\text { Not manifested in the neonatal period: } \\
\text { - Fanconi anemia (FA) } \\
\text { - Dyskeratosis congenita (DC) }\end{array}$ & $\begin{array}{l}\text { - Immune-mediated } \\
\text { - Neonatal alloimmune thrombocytopenia } \\
\text { - Alloimmune neutropenia of infancy } \\
\text { - } \text { Drug-induced } \\
\text { - Consumption with hypersplenism vs. vascular causes } \\
\text { - Necrotizing enterocolitis } \\
\text { - Pseudo-neutropenia } \\
\text { - Pseudo-thrombocytopenia }\end{array}$ \\
\hline $\begin{array}{l}\text { Secondary } \\
\text { - Infectious: congenital infection, toxic or viral etiologies (rubella, } \\
\text { cytomegalovirus, toxoplasmosis, bacterial) } \\
- \text { Drug-induced } \\
-\quad \text { Nutritional } \\
-\mathrm{B}_{12}, \text { folate, copper }\end{array}$ & \\
\hline
\end{tabular}

Serum TFT results showed low free T4 $5.6 \mathrm{pmol} / \mathrm{L}$ (normal range 13.9-26.1 pmol/L), free T3 $3.1 \mathrm{pmol} / \mathrm{L}$ (normal range 4.5-10.5 $\mathrm{pmol} / \mathrm{L}$ ), and high TSH was $>105 \mu \mathrm{IU} / \mathrm{mL}$ (normal range $1.4-8.8$ $\mu \mathrm{IU} / \mathrm{mL}$ ). Thyroid scintigraphy using technetium (Tc-99m pertechnetate) revealed ectopic lingual thyroid with no thyroid gland visualized in the normal position. Tc-99m pertechnetate scan is the recommended investigation in congenital hypothyroidism to delineate the etiology of either dysgenesis or dyshormonogenesis, and if it is not available, thyroid ultrasound is recommended (Fig. 1).

A diagnosis of primary congenital hypothyroidism with ectopic lingual thyroid was established, so L-thyroxine was started immediately. The follow-up of blood indices after starting thyroxine treatment showed marked improvement in leukocyte, neutrophil, and platelet counts. Figure 2 shows the follow-up of blood indices before and after treatment with L-thyroxine. Follow-up of thyroid function test after 4 weeks showed marked improvement, with free T4 $24.9 \mathrm{pmol} / \mathrm{L}$ and TSH $2.36 \mu \mathrm{IU} / \mathrm{mL}$. The follow-up FBC corresponded to these results, with normal WBC count $7,200 / \mu \mathrm{L}$, absolute neutrophilic count $500 / \mu \mathrm{L}$, and platelet count $224,000 / \mu \mathrm{L}$.

\section{Discussion}

Peripheral blood cytopenia is defined as reduction in either of the cellular elements of blood, i.e., red cells, white cells, or platelets. Bicytopenia is the reduction in any of the two cell lines and pancytopenia is the reduction in all three cell lines [5].
Differential diagnosis of neonatal bicytopenia is complex including physiologic or non-physiologic causes, congenital or acquired causes. Differential diagnoses of neonatal cytopenia are summarized in Table 1 [6]. There are causes related to the fetomaternal unit, which are summarized in Table 2 [7]. As peripheral blood film showed acanthocytosis, causes are summarized in Table $3[8]$.

In our case, detection of underlying etiology of bicytopenia was challenging. Causes of inherited bone failure were excluded, as there were no dysmorphic features or congenital anomalies. There was no contribution of G6PD deficiency in our case, as there was no reported anemia or jaundice. Idiopathic neutropenia of prematurity was ruled out, as there was no anemia and also due to early presentation (precursors diverted towards erythroid differentiation to compensate for anemia of prematurity). Thrombocytopenia due to intrauterine growth restriction was considered initially in our differential diagnosis, but due to the association with leukopenia, neutropenia, and the dramatic response to thyroid treatment, we assumed another underlying etiology. As there was no antenatal history of maternal disorders like diabetes nor pregnancyinduced hypertension, fetomaternal causes were also ruled out. Neonatal sepsis was excluded with repeated negative septic screenings. Absence of congenital anoma- 
Table 2. Fetomaternal causes of neonatal leukopenia and thrombocytopenia

\begin{tabular}{|c|c|}
\hline $\begin{array}{l}\text { Placental } \\
\text { insufficiency }\end{array}$ & $\begin{array}{ll}\text { - } & \text { PIH spectrum disorders } \\
\text { - } & \text { Maternal diabetes } \\
\text { - } & \text { Systemic conditions (malignancies, cardiac } \\
\text { diseases, thyroid diseases, SLE, and other } \\
\text { autoimmune disorders) }\end{array}$ \\
\hline $\begin{array}{l}\text { Immune } \\
\text { mediated } \\
\text { disorders }\end{array}$ & $\begin{array}{l}\text { - } \text { Hemolytic disease of the newborn } \\
\text { - } \quad \text { Autoimmune hemolytic anemia } \\
\text { - }\end{array}$ \\
\hline $\begin{array}{l}\text { Transplacental } \\
\text { acquired } \\
\text { infections }\end{array}$ & $\begin{array}{ll}\text { - } & \text { Toxoplasmosis } \\
- & \text { Syphilis } \\
- & \text { Tuberculosis } \\
- & \text { Malaria } \\
- & \text { Viral infections (CMV, parvovirus B19, } \\
& \text { rubella, HIV, Coxsackie B, ECHO virus) }\end{array}$ \\
\hline
\end{tabular}

Table 3. Differential diagnosis of acanthocytosis

Acute anemia

Chronic anemia

Growth failure

Hepatitis A, B, and C

Hepatorenal syndrome

Malnutrition

Panhypopituitarism

Hypothyroidism

Pediatric malabsorption syndromes

Sinonasal manifestations of cystic fibrosis

lies together with negative serology excluded the possibility of congenital infections like TORCH. Immune causes were less likely in our differential diagnosis, as the direct agglutination test was negative. In addition to that, there were two cell lines affected (platelets and leukocytes), indicating the possibility of a systemic disorder.

Thyroid hormones are known to stimulate erythropoiesis, and the physiologic effect of thyroid hormones on hematopoiesis results in changes in the red cell mass, blood volume, and iron turnover in patients with both hypo- and hyperthyroidism [4]. Macrocytosis is reported in $38 \%$ of cases of hypothyroidism, while microcytosis is reported in 2-15\% [9]. Surprisingly, our case did not have any anemia or abnormal red blood cell size. The only abnormal finding was presence of acanthocytes in peripheral blood film. It is known that there is no effect of hypothyroidism on both leukocytes and platelet count, only platelet dysfunction can be encountered in patients with hypothyroidism $[10,11]$.

Tsoukas [12] reported a case of an 82-year-old with myxedema coma presenting with pancytopenia. White cell count was $3.99 \times 10^{9} / \mathrm{L}$, hemoglobin $8.5 \mathrm{~g} / \mathrm{dL}$, hematocrit $24.9 \%$, platelet count $27,000 / \mathrm{mL}$, and mean corpuscular volume $82 \mathrm{fL} /$ cell. The patient's thyroid stimulating hormone was $291 \mathrm{mIU} / \mathrm{L}$ (normal, 0.3-4.8), with total T3 of $0.3 \mathrm{ng} / \mathrm{dL}$ (normal, 75-200) and free thyroxine of $<0.3$ ng/dL (normal, 0.8-2.8) [12].

el Mahdi Haddam et al. [13] reported 63\% hematological manifestations in a series of 100 patients suffering from hypothyroidism, with 58\% having anemia, $6 \%$ leukopenia, and $8 \%$ thrombocytopenia.

The mechanism by which pancytopenia occurs is not fully understood. In our case, the relationship between bicytopenia and hypothyroidism was evident by exclusion of all other causes of bicytopenia and the dramatic improvement after starting treatment with L-thyroxine, with normalization of blood indices corresponding to normalization of thyroid function tests in the follow-up (Fig. 2).

The diagnosis of congenital hypothyroidism is mainly by neonatal screening and thyroid function tests. The role of gene mutation analysis is not done routinely and is kept only for familial cases of congenital hypothyroidism or if associated with other congenital anomalies because it will take time to get the result and it has no impact on diagnosis and treatment.

It is well known that prognosis of congenital hypothyroidism depends on the starting time and adequacy of thyroxine treatment, regardless of the etiology. In addition, there is no difference between preterm and term infants in the aspects of diagnosis and management.

To our knowledge, this is the first reported case of congenital hypothyroidism in the neonatal period to present with bicytopenia (leukopenia, neutropenia, and thrombocytopenia) which showed improvement after starting treatment with thyroxine. We recommend that in cases of unexplained neonatal pancytopenia, congenital hypothyroidism should be considered in the differential diagnosis. We believe that affection of the blood indices in cases of congenital hypothyroidism might indicate the severity of the condition. Further studies are needed to determine the possible underlying mechanism of this possible association.

\section{Acknowledgement}

No organizations or individuals contributed to this study. 


\section{Statement of Ethics}

Written consent was taken from the parents.

\section{Disclosure Statement}

There is no conflict of interest of any of the authors with the results of this case study.

\section{Funding Sources}

No funding was received.

\section{Author Contributions}

Dr. Ahmed Elmelhat: conception, data acquisition, manuscript drafting, critical analysis, final approval. Dr. Manal Mustafa Khadora: analysis, review, design, critical analysis, final approval.

\section{References}

1 Horton L, Coburn RJ, England JM, Himsworth RL. The haematology of hypothyroidism. Q J Med. 1976 Jan;45(177):101-23.

2 Perlman JA, Sternthal PM. Effect of 131I on the anaemia of hyperthyroidism. J Chronic Dis. 1983;36(5):405-12.

3 Lima CS, Zantut Wittmann DE, Castro V, Tambascia MA, Lorand- Metze I, Saad ST, Costa FF. Pancytopenia in untreated patients with Graves' disease. Thyroid. 2006 Apr; 16(4):403-9.

4 Axelrod AR, Berman L. The bone marrow in hyperthyroidism and hypothyroidism. Blood. 1951 May;6(5):436-53.
5 Bates I, Bain BJ. Approach to diagnosis and classification of blood diseases. In: Lewis SM, Bain BJ, Bates I, editors. Dacie and Lewis Practical Haematology. 10th ed. Philadelphia: Churchill Livingstone; 2006. p. 609-24. https://doi.org/10.1016/B0-44-3066604/50027-1.

6 Bussel JB, Sola-Visner M. Current approaches to the evaluation and management of the fetus and neonate with immune thrombocytopenia. Semin Perinatol. 2009 Feb;33(1):35-42.

7 Black LV, Maheshwari A. Disorders of the fetomaternal unit: hematologic manifestations in the fetus and neonate. Semin Perinatol. 2009 Feb;33(1):12-9.

8 Hoffman R, Benz EJ, Silberstein LE, Heslop H, Weitz J, Anastasi J. Hematology: Basic Principles and Practice. 6th ed. Elsevier; 2012. ISBN: 978-1-4377-2928-3.
9 Fein HG, Rivlin RS. Anemia in thyroid diseases. Med Clin North Am. 1975 Sep;59(5): 1133-45.

10 Ansell J. the blood in hypothyroidism. In Werner and Ingbar's The Thyroid, edited by Braverman LE, Utiger RD, pp. 821-25, Philadelphia, Lippincott-Raven, 1996.

11 Klein I, Levey GS. Unusual manifestations of hypothyroidism. Arch Intern Med. 1984 Jan; 144(1):123-8.

12 Tsoukas MA. Pancytopenia in severe hypothyroidism. Am J Med. 2014 Sep;127(9):e112.

13 el Mahdi Haddam A, Fedala S, Meskine D, Chentli F, Fedala N. Hematological disorders in hypothyroidism: about a series of 100 cases. Endocrine Abstracts. 2014;35:P1020. 